\title{
PENGARUH DEBT TO ASSET RATIO, RASIO KAS, SIZE, RETURN ON ASSET, GROWTH DAN KEPEMILIKAN INSTITUSIONAL TERHADAP DIVIDEND PAYOUT RATIO PADA SEKTOR PERBANKAN
}

\author{
STEVANIUS \\ STEVEN YAP \\ Trisakti School of Management \\ iusstevanius@gmail.com
}

\begin{abstract}
The purpose of this study is to analyze and obtain empirical evidence of the effect of debt to asset ratio, cash ratio, size, return on assets, growth, and ownership Institutional dividend payout ratio. The objects used in this study is the banking sector listed in Indonesia Stock Exchange from the period 2008-2014. The sample consisted of eight companies which have been selected by purposive sampling method and analyzed using Eviews8 with multiple linear regression and random effect models to test the hypothesis. This study shows that the debt to asset ratio has an influence on the dividend payout ratio while the cash ratio, size, return on assets, growth, and institutional ownership has no effect on the dividend payout ratio. Overall, the independent variables have an effect simultaneously to the dividend payout ratio.
\end{abstract}

Keywords: Dividend payout ratio, debt to asset ratio, cash ratio, size, growth, and institutional ownership.

\begin{abstract}
Abstrak: Tujuan penelitian adalah untuk menganalisis dan mendapatkan bukti empiris pengaruh debt to asset ratio, rasio kas, size, return on asset, growth, dan kepemilikan insititusional terhadap dividend payout ratio. Objek yang digunakan dalam penelitian ini adalah sektor perbankan yang terdaftar di Bursa Efek Indonesia dari periode 2008-2014. Sampelnya terdiri dari 8 perusahaan dimana dipilih dengan metode purposive sampling dan dianalisis menggunakan Eviews8 dengan regresi linier berganda serta model random effect untuk menguji hipotesis. Hasil penelitian memperlihatkan bahwa debt to asset ratio memiliki pengaruh terhadap dividend payout ratio sementara rasio kas, size, return on asset, growth, dan kepemilikan institusional tidak memiliki pengaruh terhadap dividend payout ratio. Secara keseluruhan, variabel independen memiliki pengaruh secara simultan terhadap dividend payout ratio.
\end{abstract}

Kata kunci: Dividend payout ratio, debt to asset ratio, rasio kas, ukuran perusahaan, pertumbuhan, dan kepemilikan institusional. 


\section{PENDAHULUAN}

Pada umumnya kebijakan dividen merupakan salah satu hal penting dalam keputusan perusahaan. Tanpa adanya pendanaan, perusahaan mungkin menghadapi hilangnya kesempatan mendapatkan investasi yang menguntungkan. Perusahaan umumnya membutuhkan dana untuk mengembangkan perusahaan. Perusahaan mendapat dana secara internal maupun eksternal. Mendapatkan dana secara internal dimana kemampuan perusahaan untuk mendapatkan laba. Mendapatkan dana secara eksternal dimana perusahaan harus menarik investor, agar investor menanamkan modal kepada perusahaan. Umumnya investor melakukan investasi bertujuan untuk memperoleh pendapatan (dividend) dan selisih harga jual saham terhadap harga beli (capital gain). Dividen yang dibagikan tersebut diharapkan dapat meningkatkan kesejahteraan para pemegang saham. Investor sebagai pemegang saham berharap mendapatkan dividen yang besar atau relatif stabil dari tahun ke tahun. Investor tidak hanya melihat sisi return atau gain saja, tetapi faktor risiko atas penanaman modal.

Investor biasanya menggunakan pendekatan dasar yang disebut analisis fundamental dan analisis teknikal untuk memutuskan membeli atau menjual saham. Analisis fundamental merupakan analisis yang didasarkan pada kondisi yang ada pada saat ini, dan merupakan analisis yang paling teliti namun juga lebih rumit dibandingkan analisis teknikal.

Dividend Payout Ratio yaitu perbandingan dividen yang dibayarkan dengan laba yang tersedia bagi pemegang saham. Semakin tinggi Dividend Payout Ratio yang ditetapkan perusahaan, semakin kecil dana yang tersedia untuk diinvestasikan kembali (Reinvestment) di dalam perusahaan.

Masalah dari penelitian ini terdapat perbedaan hasil penelitian sehingga hasilnya belum jelas. Menurut Ooi (2001), menemukan bahwa Dividend Payout Ratio ditentukan oleh ukuran perusahaan (Size), aktiva (Asset), dan struktur modal (Capital Structure). Rahayu (2003), menemukan bahwa Insider Ownership, Shareholder Dispersion, Growth dan Kepemilikan Institusional memiliki pengaruh yang signifikan terhadap Dividend Payout Ratio, sedangkan Size tidak memiliki pengaruh yang signifikan terhadap Dividend Payout Ratio. Afza (2010), membuktikan bahwa kepemilikan manajerial, kepemilikan individual, arus kas operasi, dan size merupakan faktor-faktor penentu yang paling signifikan dalam pembayaran dividen, sedangkan leverage dan arus kas tidak signifikan dalam menentukan pembayaran dividen perusahaan.

Ukuran perusahaan memegang peranan dalam menjelaskan dividend payout ratio perusahaan. Perusahaan yang lebih besar cenderung lebih matang dan mempunyai akses ke pasar modal, sehingga mengurangi ketergantungan pendanaan internal.

Faktor lain yang dapat mempengaruhi kebijakan dividen juga berasal dari kepemilikan institusional (Institutional Ownership) yaitu kepemilikan saham yang dimiliki oleh institusi lain seperti: perusahaan asuransi, bank, dan institusi lainnya. Pada penelitian sebelumnya, Afza (2010), menyimpulkan bahwa kepemilikan manajerial, kepemilikan arus kas operasi dan size merupakan faktor-faktor penentu yang paling signifikan dalam pembayaran dividen, sedangkan leverage dan sensitivitas arus kas tidak secara signifikan dalam menentukan tingkat pembayaran dividen perusahaan. Berbeda dengan Rahayu (2003), menemukan bahwa Insider Ownership, Shareholder Dispersion, Growth dan Kepemilikan Institusional memiliki pengaruh yang signifikan terhadap Dividend Payout Ratio, sedangkan Size tidak memiliki pengaruh yang signifikan terhadap Dividend Payout Ratio. 
Growth yaitu pertumbuhan perusahaan yang ditandai dengan bertambahnya kapitalisasi pasar, sales atau asset akan memberikan pengaruh yang positif terhadap efisiensi dana yang dipegang oleh perusahaan sehingga menghasilkan pengembalian yang dapat digunakan kembali untuk membayar dividen maupun mengembangkan operasi perusahaan. Perusahaan dengan tingkat pertumbuhan penjualan dan laba yang tinggi, cenderung membagikan dividen lebih konsisten dibanding perusahaan yang tingkat pertumbuhan penjualannya rendah, sehingga pertumbuhan perusahaan akan berpengaruh signifikan terhadap Dividend Payout Ratio. Menurut Rahayu (2003), menyimpulkan bahwa variable growth berpengaruh signifikan terhadap Dividend Payout Ratio.
Cash Ratio merupakan ukuran yang lazim digunakan untuk mengukur likuiditas, sehingga Cash Ratio juga berpengaruh terhadap pendapatan dividen. Cash ratio adalah "Rasio likuiditas yang paling konservatif yang menghubungkan uang kas perusahaan dan surat berharga dengan pasiva lancar. (Sundjaja et al. 2013, 181).

Menurut Gitman and Zutter $(2015,70)$ institutional ownership merupakan "Investasi profesional seperti bank, perusahaan asuransi, reksadana, dan dana pensiun yang dibayar untuk mengelola dan menahan sejumlah besar efek atas nama orang lain."

Objek yang dipilih merupakan perusahaanperusahaan pada sektor perbankan yang terdaftar di BEI dikarenakan sektor tersebut memiliki keunggulan dibandingkan dengan sektor bukan keuangan lainnya.

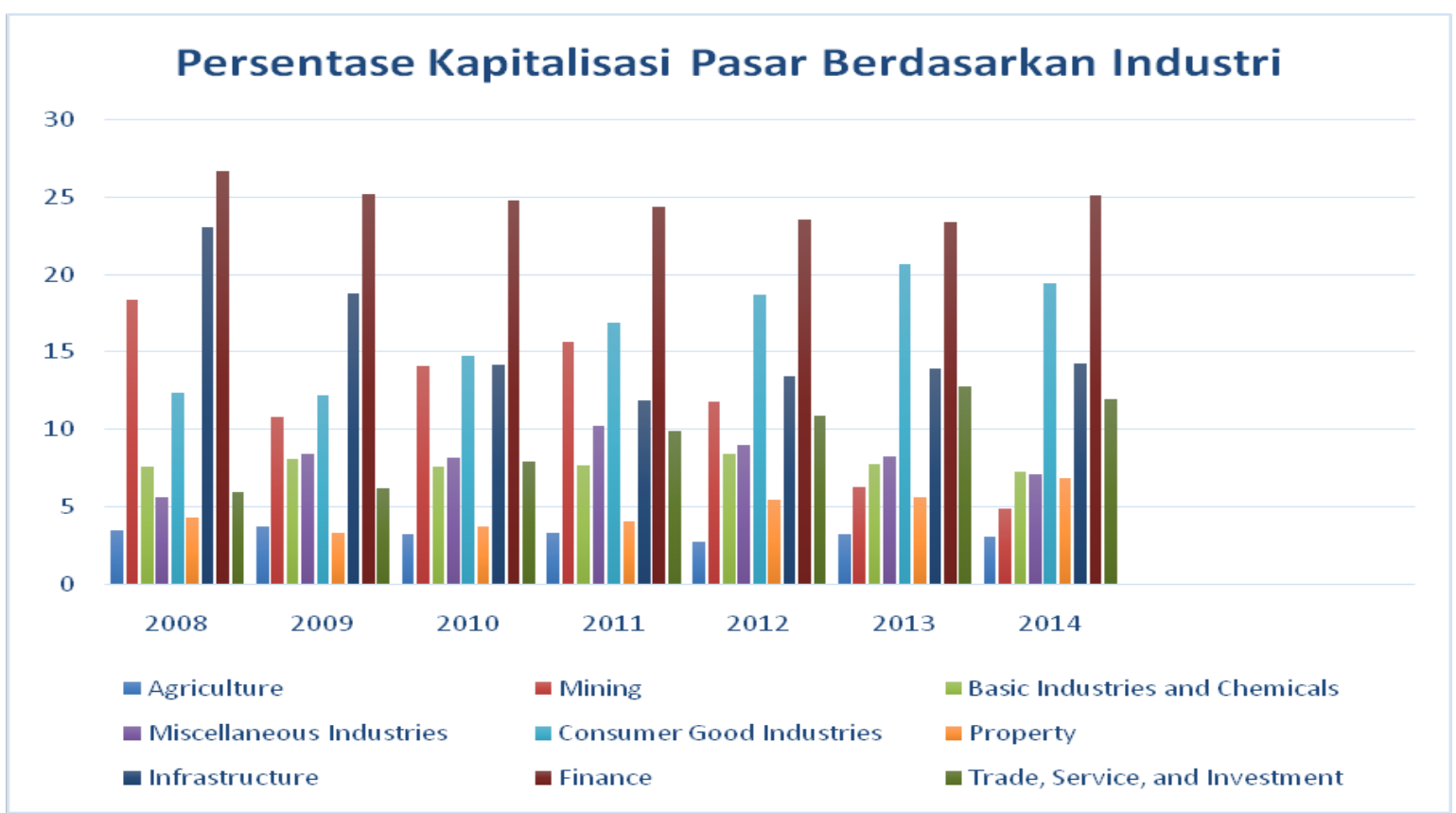

Sumber: IDX Statistic 2008-2014, data diolah

\section{Gambar 1 Persentase Kapitalisasi Pasar Berdasarkan Industri}

Alasan yang digunakan dalam penelitian ini bahwa persentase kapitalisasi pasar berdasarkan industri, sektor perbankan merupakan sektor unggulan dibandingkan dengan sektor lainnya. Namun peneliti menemukan alasan lain untuk membuktikan bahwa sektor perbankan menarik untuk diteliti. 


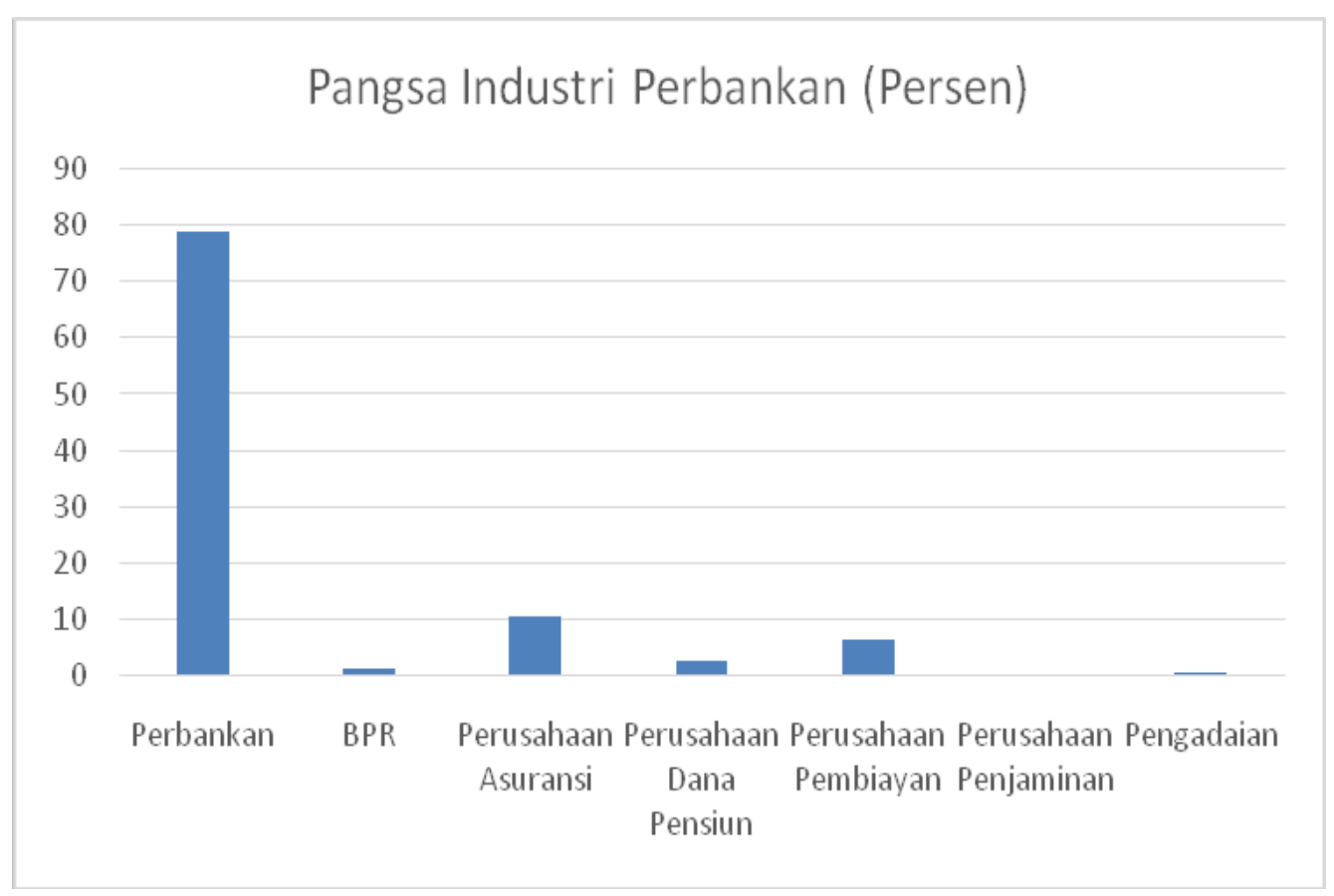

Sumber: Otoritas Jasa Keuangan (OJK), data diolah

\section{Gambar 2 Pangsa Industri Perbankan}

Dari gambar 2 di atas dapat diketahui bahwa sektor perbankan merupakan sektor unggulan berdasarkan jumlah aset perusahaan dibandingkan dengan perusahaan keuangan lainnya di Indonesia. Selain itu, berdasarkan Persentase Volume Trading Saham Sektor Ke- uangan pada tabel 1 di bawah menunjukkan bahwa Sektor Bank mempunyai volume trading saham terbesar selama 7 tahun, dengan nilai berturut-turut dari tahun 2008-2014 yaitu 93,16\%, $67,97 \%, 75,39 \%, 63,75 \%, 63,41 \%, 65,62 \%, 66,77 \%$

Tabel 1 Persentase Volume Trading Saham Sektor Keuangan

\begin{tabular}{llrrrrrrr}
\hline \multirow{2}{*}{ No } & \multirow{2}{*}{ Industry Classification } & \multicolumn{7}{c}{ Volume Trading Saham (\%) } \\
& & 2008 & 2009 & 2010 & 2011 & 2012 & 2013 & 2014 \\
\hline 1 & Bank & 93,16 & 67,97 & 75,39 & 63,75 & 63,41 & 65,62 & 66,77 \\
2 & Financial Institution & 0,95 & 4,18 & 6,26 & 5,92 & 5,57 & 3,88 & 2,01 \\
3 & Securities Company & 0,99 & 3,55 & 3,15 & 1,65 & 5,04 & 4,35 & 5,93 \\
4 & Insurance & 3,99 & 21,81 & 11,35 & 11,21 & 17,98 & 0,93 & 3,49 \\
5 & Investment Fund/Mutual Fund & 0 & 0 & 0 & 0 & 0 & 0 & 0 \\
6 & Others & 0,91 & 2,49 & 3,85 & 17,46 & 8,01 & 25,22 & 21,80 \\
\hline & Total & 100 & 100 & 100 & 100 & 100 & 100 & 100 \\
\hline
\end{tabular}

Sumber : IDX Statistic 2008-2014 
Tabel 2 Persentase Kapitalisasi Pasar Sektor Keuangan

\begin{tabular}{llrrrrrrr}
\hline \multirow{2}{*}{ No Finance Sectors } & \multicolumn{7}{c}{ Market Capitalization (\%) } \\
\cline { 3 - 8 } & & 2008 & 2009 & 2010 & 2011 & 2012 & 2013 & 2014 \\
\hline 1 & Bank & 95,80 & 93,97 & 94,38 & 92,39 & 92,58 & 92,78 & 93.04 \\
2 & Financial Institutions & 1,40 & 2,00 & 2,45 & 2,62 & 1,87 & 2,08 & 1,78 \\
3 & Securities Company & 0,57 & 0,39 & 0,30 & 0,31 & 0,61 & 0,97 & 0,67 \\
4 & Insurance & 1,09 & 1,02 & 1,06 & 0,80 & 0,96 & 0,84 & 0,89 \\
5 & Investment Fund/Mutual Funds & 0 & 0 & 0 & 0 & 0 & 0 & 0 \\
6 & Others & 1,14 & 2,62 & 1,81 & 3,88 & 3,98 & 3,33 & 3,62 \\
\hline & Total & 100 & 100 & 100 & 100 & 100 & 100 & 100 \\
\hline
\end{tabular}

Sumber : IDX Statistic 2008-2014

Berdasarkan Nilai Kapitalisasi Pasar Sektor Keuangan pada tabel 1.2 di atas menunjukkan bahwa Sektor Perbankan memberikan kontribusi nilai kapitalisasi terbesar dibandingkan dengan sektor keuangan lainnya.

Alasan peneliti menggunakan periode 2008-2014 dalam penelitian ini karena periode tersebut didapatkan data terbanyak untuk dilakukan penelitian, yaitu terdapat delapan perusahaan dengan periode tujuh tahun, sehingga didapatkan data sebanyak lima puluh enam.

Berdasarkan hasil penelitian terdahulu terdapat persamaan maupun perbedaan. Dengan adanya perbedaan hasil penelitian tersebut dapat terjadi karena beberapa alasan seperti, perbedaan sampel dan periode penelitian, interpretasi peneliti terhadap laporan keuangan perusahaan atas variabel yang digunakan maupun perbedaan metode pengujian yang ditempuh oleh peneliti. Dengan demikian penelitian ini menarik untuk dilakukan karena untuk menganalisis berbagai perbedaan hasil penelitian sebelumnya yang satu dengan yang lainnya tentang faktor-faktor apa saja yang mempengaruhi Dividend Payout Ratio.

Menurut Gitman and Zutter $(2015,630)$ "Dividend payout ratio indicates the percentage of each dollar earned that a firm distributes to the owners in the form of cash. It is calculated by dividing the firm's cash dividend per share by its earning per share." Menurut teori ini, rasio pem-bayaran dividen menunjukkan persentase setiap uang tunai yang didistribusikan kepada pemilik saham. Rasio ini dihitung dengan membanding-kan dividen tunai per saham dan laba per saham. Dividen ini di ambil dari laba bersih yang diper-oleh oleh perusahaan pada periode tertentu. Menurut Residual Theory of Dividend, dividen yang dibayarkan perusahaan harus dipandang sebagai jumlah yang tersisa setelah semua peluang investasi didanai.

Menurut Gitman and Zutter $(2015,126)$ Debt to Asset Ratio adalah "Measures the proportion of total assets financed by the firm's creditors".Menurut Darmawi, Herman (2014, 3639), "yang termasuk liabilitas dalam perbankan adalah rekening giro, tabungan, simpanan berjangka, surat berharga yang diterbitkan, pinjaman yang diterima, pinjaman subordinasi, kewajiban sewa guna usaha, beban yang masi harus dibayar, taksiran hutang pajak, kewajiban lain, hak minoritas dalam anak perusahaan, dan agio saham. Yang termasuk aset adalah kas, rekening giro pada Bank Indonesia, rekening giro pada Bank lain, rekening penempatan pada bank lain, rekening surat berharga yang dimiliki, rekening kredit yang diberikan, pendapatan yang masih akan diterima, dan biaya yang dibayar dimuka".

Menurut Sundjaja, et al $(2013,181)$ cash ratio adalah "Rasio likuiditas yang paling konser- 
vatif yang menghubungkan uang kas perusahaan dan surat berharga dengan pasiva lancar."

Menurut Darmawi, Herman (2014, 36-38) "yang termasuk liabilitas lancar dalam perbankan adalah rekening giro, tabungan, dan kewajiban segera lainnya".

Sudarsi (2002) dalam Henny Ritha dan Eko Koestiyanto "ukuran perusahaan adalah logaritma natural dari total aktiva".

Menurut Hartono (2013,392), "Pada dasarnya ukuran perusahaan dapat di ukur sebagai logaritma dari total aktiva".

Menurut Brown dan Relly $(2012,150)$, "Ukuran suatu perusahaan dapat diukur dengan melihat jumlah total ekuitas, total penjualan atau total aktiva yang dimiliki oleh perusahaan tersebut." Dari teori-teori di atas dapat disimpulkan bahwa Size merupakan ukuran besar atau kecilnya suatu perusahaan yang dapat ditentukan dari total aktiva, total ekuitas, dan total penjualan yang dimiliki oleh perusahaan tersebut.

Menurut Cornett, et al $(2015,87)$ return on asset adalah "Measures the overall return on the firm's assets, including financial leverage and taxes".

Menurut Sundjaja, et al $(2013,191)$ Return on Asset adalah "ukuran keseluruhan keefektifan manajemen dalam menghasilkan laba dengan aktiva yang tersedia disebut juga hasil atas investasi."

Menurut Gitman and Zutter $(2015,130)$ "Measures the overall effectiveness of management in generating profits with its available assets, also called the return on investment (ROI)." Dengan demikian dapat disimpulkan bahwa Return on Total Asset mengukur kemampuan perusahaan menghasilkan laba dengan menggunakan total aset setelah perusahaan perusahaan

\section{METODE PENELITIAN}

Objek penelitian yang digunakan dalam penelitian ini adalah perusahaan-perusahaan melakukan penyesuaian dengan biaya-biaya untuk mendanai aset tersebut.

Menurut Ross, Westerfield, et al (2015, 68), "Jika penjualan tumbuh, aset juga harus tumbuh, setidaknya dalam jangka panjang. Kemampuan perusahaan untuk tumbuh tergantung pada kegiatan keuangan perusahaan."

Menurut Hartono (2013, 391), "Growth didefinisikan sebagai penambahan (tingkat pertumbuhan) tahunan dari total aktiva."

"Kepemilikan saham oleh investor institusi seperti dana pensiun, reksadana, dana lindung nilai, dan perusahaan asuransi umum memegang sebagian besar saham suatu perusahaan" (Madura 2012, 472)

"Kepemilikan institusional adalah kepemilikan saham oleh lembaga institusi seperti bank komersial, asosiasi simpan pinjam, koperasi kredit, dana pensiun, perusahaan asuransi jiwa, reksadana." (Brigham et al 2005, 47).

perbankan yang terdaftar di Bursa Efek Indonesia (BEI) yang mempublikasikan laporan keuangan tahunannya selama periode 20082014. Pemilihan sampel penelitian dilakukan 
dengan teknik non-probability sampling, yaitu metode purposive sampling. Menurut Sugiyono (2014, 122), purposive sampling adalah teknik sampel dengan pertimbangan tertentu. Oleh sebab itu, pertimbangan (kriteria) yang digunakan untuk menentukan jumlah sampel yang digunakan dalam penelitian ini adalah sebagai berikut:

1. Perusahaan harus terdaftar pada Bursa Efek Indonesia selama kurun waktu 2008 - 2014.

2. Perusahaan yang dipilih adalah perusahaan sektor perbankan.

3. Menerbitkan laporan keuangan secara berturut-turut pada bursa efek selama periode 2008-2014.

4. Menerbitkan laporan keuangan dalam satuan mata uang Rupiah (Rp).

5. Secara berturut-turut membagikan dividen kas selama periode 2008-2014.

6. Objek penelitian memiliki informasi lengkap mengenai variabel yang dibutuhkan dalam penelitian.

7. Dividen yang dibagikan hanya dividen tunai.

Dividend Payout Ratio merupakan persentase jumlah laba bersih yang tersedia bagi pemegang saham biasa dan diberikan oleh perusahaan dalam bentuk uang tunai. Menurut Gitman dan Zutter $(2015,630)$ menghitung dividend payout ratio dirumuskan sebagai berikut :

Dividend Payout Ratio $=$ Cash Dividend per share Earning per share

Debt to Asset Ratio merupakan rasio antara total hutang baik hutang jangka panjang maupun hutang jangka pendek terhadap total aktiva. Menurut Gitman dan Zutter $(2015,126)$ menghitung debt to asset ratio dirumuskan sebagai berikut:

Debt to Asset Ratio $=\underline{\text { Total Liabilities }}$ Total Assets

Cash Ratio merupakan rasio yang digunakan untuk menghitung likuiditas perusahaan.
Menurut Cornett, et al $(2015,78)$ menghitung cash ratio dirumuskan sebagai berikut:

Cash Ratio $=\underline{\text { Cash }+ \text { Marketable Securities }}$ Current Liabilities

Size merupakan ukuran yang digunakan untuk menentukan besar atau kecilnya suatu perusahaan. Demikian rumus yang digunakan menurut Henny Ritha dan Eko Koestiyanto (2013) rumus yang digunakan adalah :

Size $=$ Natural Log Total Asset

Return on Asset (ROA) menunjukkan efektivitas perusahaan memanfaatkan dana untuk kepentingan perusahaan. Demikian rumus yang digunakan menurut Henny Ritha dan Eko Koestiyanto (2013) rumus yang digunakan adalah :

$$
R O A=\frac{\text { Net Income After Tax }}{\text { Total Assets }}
$$

Growth pada penelitian ini mengukur perubahan positif maupun negatif dari aset, profitabilitas atau sales yang di alami perusahaan setiap tahunnya. Perusahaan yang baik memiliki pertumbuhan secara positif. Demikian rumus yang digunakan menurut Zahra Lashgari dan Mousa Ahmadi (2014) rumus yang digunakan adalah :

\section{Growth it $=\Delta$ ASSET it ASSET it-1}

$\Delta$ ASSET it $=$ ASSET it - ASSET it-1

Institutional Ownership merupakan persentase kepemilikan saham oleh institusi keuangan. Menghitung kepemilikan institusional dirumuskan sebagai berikut :

\section{Kepemilikan Institusional $=$}

Jumlah Saham yang dimiliki institusi x $100 \%$ Jumlah saham beredar 


\section{HASIL PENELITIAN}

Penelitian ini menggunakan data keuangan dari tahun 2006 sampai dengan tahun 2014 pada perusahaan telekomunikasi yang terdaftar di Bursa Efek Indonesia, serta data keuangan yang lengkap selama periode penelitian. Dari kriteria di atas, maka total data yang digunakan sebanyak 45 .

Tabel 3 Hasil Statistik Deskriptif

\begin{tabular}{lccccccc}
\hline & $\begin{array}{c}\text { DIVIDEND } \\
\text { PAYOUT } \\
\text { RATIO }\end{array}$ & $\begin{array}{c}\text { DEBT TO } \\
\text { TOTAL ASSET } \\
\text { RATIO }\end{array}$ & SIZE & $\begin{array}{c}\text { RETURN } \\
\text { ON } \\
\text { ASSET }\end{array}$ & GROWTH & $\begin{array}{c}\text { INSTITUTIONAL } \\
\text { OWNERSHIP }\end{array}$ & $\begin{array}{c}\text { CASH } \\
\text { RATIO }\end{array}$ \\
\hline Mean & 0.281980 & 0.873871 & 32.09009 & 0.018023 & 0.141995 & 0.513270 & 0.118366 \\
Maximum & 0.735200 & 0.939100 & 34.38217 & 0.034100 & 0.536200 & 0.909000 & 0.434300 \\
Minimum & 0.107000 & 0.762400 & 28.31268 & 0.000400 & -0.055600 & 0.048200 & 0.022900 \\
Std. Dev. & 0.109921 & 0.041142 & 1.970230 & 0.008486 & 0.092671 & 0.257796 & 0.081457 \\
Observations & 56 & 56 & 56 & 56 & 56 & 56 & 56 \\
\hline
\end{tabular}

Sumber: Hasil Pengolahan Eviews 8

Tabel 4 Hasil Uji t

\begin{tabular}{lcccl}
\hline Model & B & T & Prob & Kesimpulan \\
\hline DAR & 0.941646 & 2.590952 & 0.0123 & Ho dapat ditolak \\
SIZE & 0.012181 & 1.383473 & 0.1722 & Ho tidak dapat ditolak \\
ROA & -3.786200 & -1.880909 & 0.0654 & Ho tidak dapat ditolak \\
GROWTH & -0.275650 & -1.607605 & 0.1138 & Ho tidak dapat ditolak \\
KEP_INST & 0.023955 & 0.352794 & 0.7256 & Ho tidak dapat ditolak \\
CASH_R & 0.157653 & 0.849215 & 0.3995 & Ho tidak dapat ditolak \\
\hline
\end{tabular}

Sumber: Hasil pengolahan Eviews8

Dependent Variable: DPR

Hasil penelitian menunjukkan bahwa debt to asset ratio memiliki nilai t statistic lebih besar dari t table atau t kritis (2.590952> 2.0049), sehingga nilai t statistic berada di region of rejection dan dapat disimpulkan bahwa $\mathrm{H}_{0}$ ditolak. Kesimpulan ini didukung oleh nilai probabilitas debt to asset ratio, yaitu sebesar 0.0123 yang lebih kecil dari nilai a $(0.0123<0.05)$. Hal ini berarti $\mathrm{H}_{0}$ ditolak, sehingga dapat disimpulkan bahwa terdapat pengaruh debt to asset ratio terhadap dividend payout ratio pada sektor perbankan yang terdaftar di Bursa Efek Indonesia periode $2008-2014$.
Hasil penelitian menunjukkan bahwa size memiliki nilai t statistic lebih kecil dari t table atau $t$ kritis $(1.383473<2.0049)$, sehingga nilai $t$ statistic berada di region of acception dan dapat disimpulkan bahwa $\mathrm{H}_{0}$ tidak dapat ditolak. Kesimpulan ini didukung oleh nilai probabilitas size, yaitu sebesar 0.1722 yang lebih besar dari nilai a $(0.1722>0.05)$. Hal ini berarti $\mathrm{H}_{0}$ tidak dapat ditolak, sehingga dapat disimpulkan bahwa tidak terdapat pengaruh size terhadap dividend payout ratio pada sektor perbankan yang terdaftar di Bursa Efek Indonesia periode 2008 - 2014. 
Hasil penelitian menunjukkan bahwa return on asset memiliki nilai t statistic lebih kecil dari t table atau t kritis $(-1.880909<-2.0129)$, sehingga nilai t statistic berada di region of acception dan dapat disimpulkan bahwa $\mathrm{H}_{0}$ tidak dapat ditolak. Kesimpulan ini didukung oleh nilai probabilitas return on asset, yaitu sebesar 0.0654 yang lebih besar dari nilai a $(0.0654>0.05)$. Hal ini berarti $\mathrm{H}_{0}$ tidak dapat ditolak, sehingga dapat disimpulkan bahwa tidak terdapat pengaruh return on asset terhadap dividend payout ratio pada sektor perbankan yang terdaftar di Bursa Efek Indonesia periode 2008 - 2014.

Hasil penelitian menunjukkan bahwa growth memiliki nilai t statistic lebih kecil dari t table atau t kritis $(-1.607605<-2.0129)$, sehingga nilai $t$ statistic berada di region of acception dan dapat disimpulkan bahwa $\mathrm{H}_{0}$ tidak dapat ditolak. Kesimpulan ini didukung oleh nilai probabilitas growth, yaitu sebesar 0.1138 yang lebih besar dari nilai a $(0.1138>0.05)$. Hal ini berarti $\mathrm{H}_{0}$ tidak dapat ditolak, sehingga dapat disimpulkan bahwa tidak terdapat pengaruh growth terhadap dividend payout ratio pada sektor perbankan yang terdaftar di Bursa Efek Indonesia periode 2008 - 2014.

Hasil penelitian menunjukkan bahwa institutional ownership memiliki nilai t statistic lebih kecil dari t table atau t kritis $(0.352794<$ 2.0129), sehingga nilai t statistic berada di region of acception dan dapat disimpulkan bahwa $\mathrm{H}_{0}$ tidak dapat ditolak. Kesimpulan ini didukung oleh nilai probabilitas institutional ownership, yaitu sebesar 0.7256 yang lebih besar dari nilai a $(0.7256>0.05)$. Hal ini berarti $\mathrm{H}_{0}$ tidak dapat ditolak, sehingga dapat disimpulkan bahwa tidak terdapat pengaruh institutional ownership terhadap dividend payout ratio pada sektor perbankan yang terdaftar di Bursa Efek Indonesia periode 2008 - 2014.

Hasil penelitian menunjukkan bahwa cash ratio memiliki nilai t statistic lebih kecil dari $t$ table atau $t$ kritis $(0.849215<2.0049)$, sehingga nilai t statistic berada di region of acception dan dapat disimpulkan bahwa $\mathrm{H}_{0}$ tidak dapat ditolak.
Kesimpulan ini didukung oleh nilai probabilitas cash ratio, yaitu sebesar 0.3995 yang lebih besar dari nilai a $(0.3995>0.05)$. Hal ini berarti $\mathrm{H}_{0}$ tidak dapat ditolak, sehingga dapat disimpulkan bahwa tidak terdapat pengaruh cash ratio terhadap dividend payout ratio pada sektor perbankan yang terdaftar di Bursa Efek Indonesia periode 2008 - 2014.

\section{PENUTUP}

Berdasarkan hasil penelitian dapat di simpulkan sebagai berikut : Debt to Asset Ratio berpengaruh terhadap dividend payout ratio pada sektor perbankan. Hasil pene-litian ini tidak konsisten dengan penelitian yang dilakukan oleh Puspita (2009) yang menyatakan tidak berpengaruh secara signifikan terhadap dividend payout ratio. Tetapi konsisten dengan hasil penelitian yang dilakukan oleh Ritha dan Koestiyanto (2013) yang menyatakan bahwa terdapat pengaruh secara signifikan terhadap dividend payout ratio. Menurut Henny Ritha dan Eko Koestiyanto (2013) bahwa dengan total hutang atau Leverage yang lebih besar memberikan manfaat berupa menambah pendapatan bagi pemegang saham.

Size tidak berpengaruh terhadap dividend payout ratio pada sektor perbankan. Hasil penelitian ini konsisten dengan Tania (2014). Menurut Tania (2014), hal ini dikarenakan dalam perekonomian yang mulai membaik tahun 2009-2012, baik perusahaan kecil maupun perusahaan besar akan lebih ber-orientasi pada pengembangan usaha guna memperluas pasar. Serta kondisi ekonomi sangat mempengaruhi operasional dan lebih mengutamakan bahan operasional tersebut dibandingkan devidennya. Demikian grafik perekonomian Indonesia tahun 2009-2012. Meskipun kondisi ekonomi dunia masih pe-nuh dengan risiko, ekonomi Indonesia dapat tumbuh di atas 6 persen. 


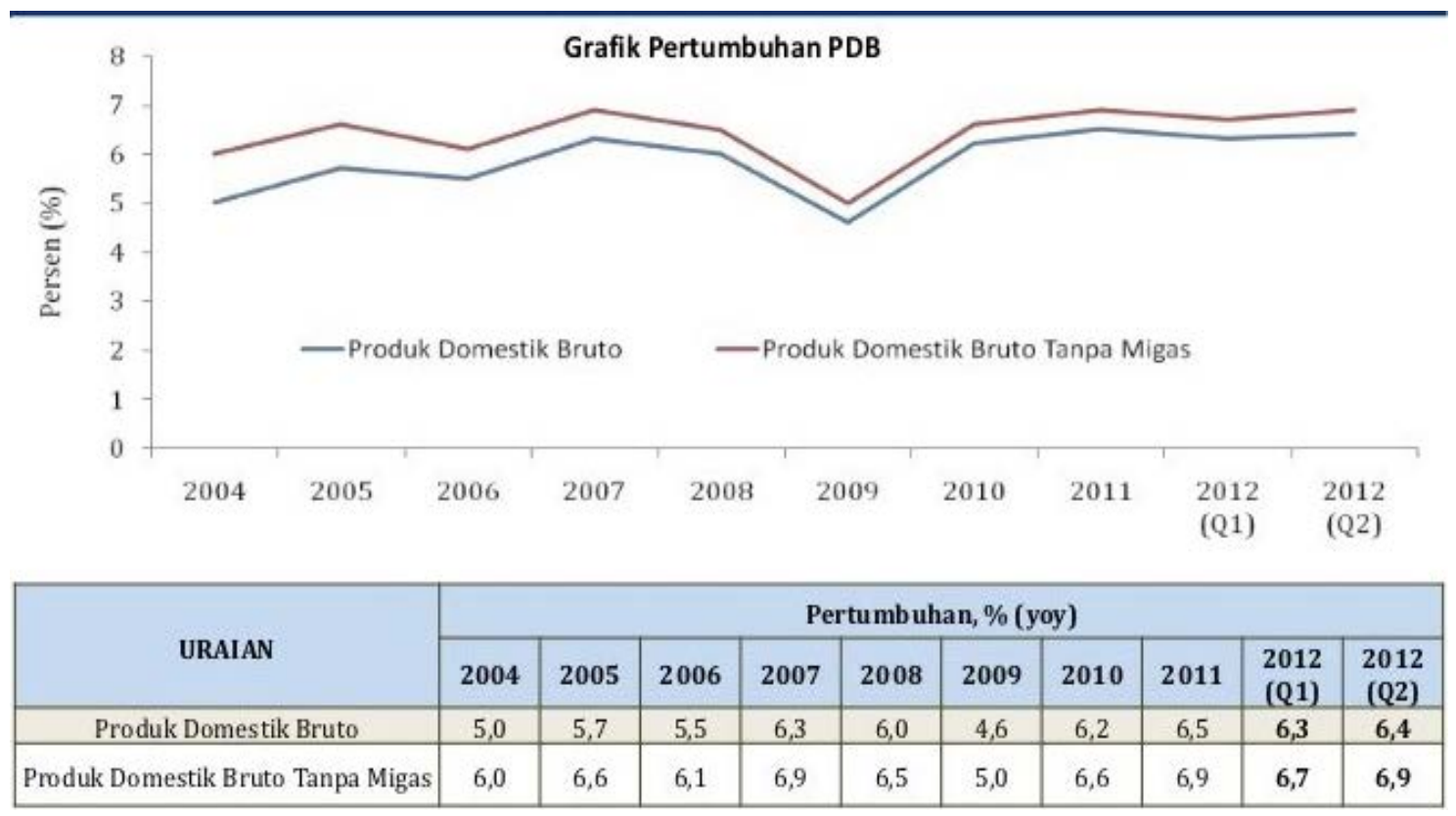

Sumber : Badan Pusat Statistik (Data Diolah)

\section{Gambar 3 Pertumbuhan GDP Indonesia tahun 2004 - 2012}

Return on Asset tidak berpengaruh terhadap dividend payout ratio pada sektor perbankan. Hasil penelitian ini tidak konsisten dengan penelitian yang dilakukan oleh Marlina dan Danica (2009) yang menyatakan berpengaruh secara signifikan terhadap dividend payout ratio, tetapi konsisten dengan penelitian yang dilakukan oleh Anil and Kapoor (2008), yang menyatakan bahwa tidak ada pengaruh secara signifikan terhadap dividend payout ratio. Meskipun profitabilitas memiliki korelasi positif terhadap deviden, tetapi bukan menjadi faktor penentu dalam pembayaran deviden atau pengaruh-nya tidak signifikan.

Growth tidak berpengaruh terhadap dividend payout ratio pada sektor perbankan. Hasil penelitian ini konsisten dengan penelitian yang dilakukan oleh Marietta (2013), Tania (2014). Menurut Tania (2014), Asset Growth sering dialokasikan untuk kegiatan operasional sehingga banyak asset perusahaan ditahan dan tidak berpengaruh terhadap deviden.

Institutional Ownership tidak berpengaruh terhadap dividend payout ratio pada sektor perbankan yang terdaftar di Bursa Efek Indonesia. Hasil penelitian ini konsisten dengan penelitian yang dilakukan oleh Suprihati (2015) dan Amidu and Abor (2006). Semakin tinggi persentase kepemilikan institusional semakin rendah rasio pembayaran deviden. Perusahaan membayar deviden untuk menghindari biaya yang terkait dengan agency cost.

Cash Ratio tidak berpengaruh terhadap dividend payout ratio pada sektor perbankan yang terdaftar di Bursa Efek Indonesia. Hasil ini konsisten dengan penelitian Hendrianto (2013), dan Suprihati (2015). Menurut Suprihati (2015), hal ini terjadi jika cash ratio dari operasi perusahaan meningkat maka dividend payout ratio menurun. 


\section{REFERENSI}

Afza, Talat. 2010. "Ownership Structure and Cash Flows As Determinants of Corporate Dividend Policy in Pakistan". International Business Research, Vol. 3. No. 3, July.

Amidu, Mohammed., dan Joshua Abor. 2006. "Determinants of dividend payout ratio in Ghana". The Journal of Risk Finance, Ghana.

Anderson, David R., Dennis J. Sweeney, and Thomas A. Williams. 2014. Statistic for Business and Economics $12^{\text {th }}$ Edition. South-Western: Cengage Learning.

Brealey, Richard A. and Myers, Stewart C. 2015. Fundamentals of corporate finance (International Edition). New York: Mc. Graw-Hill Companies, Inc.

Brigham, Eugene F., Joel F. Houston . 2014. "Essentials of Financial Management Third Edition". Singapore : Cengage Learning Asia.

Brigham, Eugene F., and Michael C. Ehrhardt. 2005. Financial Management : Theory and Practice $11^{\text {th }}$ Edition. USA : Thomson South - Western.

Brown, Keith C. and Frank K.Reilly. 2012. Analysis of Investments \& Management Portofolios. 10 th edition. USA : South - Western Cengage Learning.

Cornett, Marcia Millon., et al . 2015. "Finance : Applications \& Theory Third Edition". New York : McGraw-Hill Education.

Darmawi, Herman. 2014. "Manajemen Perbankan". Jakarta : Bumi Aksara.

Gitman, Lawrence J., and Chad J. Zutter. 2015. "Principles of managerial finance 14th edition". United States of America: Pearson Education Limited.

Gujarati, Damodar N., and Dawn C. Porter. 2009. Basic Econometrics. New York : McGraw-Hill.

Hair, Joseph F., and William C. Black. 2010. Multivariate Data Analysis : A Perspective $7^{\text {th }}$ Edition. New Jersey : Pearson Education.

Hartono, Jogiyanto. 2013. "Teori Portofolio dan Analisis Investasi Edisi Ketujuh. BPFE Yogyakarta : Yogyakarta.

Hendrianto, Samino. 2013. "Analisis Cash Ratio, Debt to Equity Ratio, Return on asset, growth, dan pengaruhnya terhadap Dividend Payout Ratio pada perusahaan pertambangan yang terdaftar di Bursa Efek Indonesia". Jurnal Tekun Vol. IV No. 02, Jakarta.

Keown, Arthur J., et al. 2014. "Financial Management Principles and Applications". Pearson Education Limited. United States of America.

Keown, Arthur J., John D. Martin., et al . 2014."Foundations of Finance : The Logic and Practice of Financial Management Eight Edition". Pearson Education Limited. England.

Madura, Jeff. 2012. "International Corporate Finance $11^{\text {th }}$ edition ". Cengage Learning. South-Western: Canada.

Marietta, Unzu. 2013. "Analisis Pengaruh Cash Ratio, Return on Assets, Growth, Firm Size, Debt to Equity Ratio terhadap Dividend Payout Ratio pada perusahaan manufaktur yang terdaftar di BEl periode 2008-2011". Skripsi Program Sarjana Fakultas Ekonomika dan Bisnis Universitas Diponegoro, Semarang.

Marlina, Lisa., dan Clara Denica. 2009. "Analisis Pengaruh Cash Position, Debt to Equity Ratio, Return on Asset terhadap Dividend Payout Ratio" . Jurnal Manajemen Bisnis Vol.2. Web. http://repository.usu.ac.id/bitstream/123456789/21122/1/jmb-jan2009-2\%20(4).pdf

Neolaka, Amos. 2014. "Metode Penelitian dan Statistik". Penerbit: PT Remaja Rosdakarya. Bandung.

Ooi , T.L.J . 2001. "Dividend Payout Characteristics of U. K. Property Companies". Journal of Real Estate Portofolio Management, April-June, Vol. 7. No. 2.

Puspita, Fira. 2009. "Analisis Faktor-Faktor yang mempengaruhi Dividend Payout Ratio pada perusahaan yang terdaftar di BEl periode 2005-2007". Thesis Program Pasca Sarjana Magister Manajemen Universitas Diponegoro, Semarang.

P. Tampubolon, Manahan. 2013. Finance Management. Jakarta : Mitra Wacana Media. 
Putri, Devianti. 2015. "Pengaruh Cash Position, Firm Size, Growth Opportunity, Institutional Ownership, dan Return On Asset terhadap Dividend Payout Ratio pada perusahaan consumer goods yang terdaftar di BEl periode 2001-2013". Skripsi Program Sarjana Ekonomi Trisakti School of Management, Jakarta.

Rahayu, Ira Paramitha. 2003. "Analisis Faktor-Faktor yang mempengaruhi Rasio Pembayaran Dividen pada Perusahaan Go Public di Bursa Efek Jakarta Periode 1999-2000". Thesis Program Pasca Sarjana Magister Manajemen Universitas Diponegoro, Semarang.

Ritha, Henny., dan Eko Koestiyanto. 2013. "Faktor-faktor yang mempengaruhi Dividend Payout Ratio". E-Jurnal Manajemen dan Bisnis Vol. 1 No.1.

Ross, Stephen A., Randolph W. Westerfield, et al . 2015. "Essentials of Corporate Finance Asia Global Edition". New York : McGraw-Hill Education.

Sanders, Donald H., and Robert K. Smidt. 2000. "Statistics". 6 $6^{\text {th }}$ Edition. United States of America: McGraw-Hill.

Sekaran, Uma, and Roger Bougie. 2013. Research Methods for Business: A Skill-Building Approach. $6^{\text {th }}$ Edition. John Willey \& Sons, Inc. Italy.

Sugiyono. 2014. Metode Penelitian Bisnis : Pendekatan Kuantitatif, Kualitatif, R\&D. Bandung : Alfabeta cv.

Sundjaja, Ridwan S ., et al . 2013. Manajemen Keuangan 1. Edisi 8. Liberata Lintas Media. Jakarta.

Suprihati. 2015. "Pengaruh Cash Ratio, Debt to Equity Ratio, Market to Book Value Ratio, Institutional Ownership dan Return on Asset terhadap Dividend Payout Ratio pada perusahaan yang termasuk Tertiary sectors di Bursa Efek Indonesia". Jurnal Paradigma Vol. 12 No. 02, Surakarta.

Tania, Liza. 2014. "Analisis Pengaruh Cash Position, Debt to Equity Ratio, Return on Asset, Cash Ratio, Asset Growth, dan Firm Size terhadap Dividend Payout Ratio". Jurnal Manajemen Bisnis. Web. http://eprints.dinus.ac.id/8685/.

Widarjono, Agus. 2013. Ekonometrika Pengantar dan Aplikasinya Disertai Panduan Eviews. Edisi keempat. Yogyakarta: UPP STIM YKPN.

Zahra Lashgari and Mousa Ahmadi.2014. "The Impact of Dividend Policy On Stock Price Volatility in The Tehran Stock Exchange". Kuwait Chapter of Arabian Journal of Business and Management Review Vol.3. No.10: June. 